\title{
Pengembangan UMKM dengan Transformasi Digital dalam Rangka Pertahanan Ekonomi Ditengah Pandemi Covid-19 di Dusun Bendo, Desa Seboto, Kecamatan Gladagsari, Kabupaten Boyolali
}

\author{
Rika Desi Ernawati ${ }^{a, 1}$, Sigit Muryanto ${ }^{b, 2, *}$ \\ ${ }^{a}$ Fakultas Ekonomi, Universitas Boyolali, Jl. Pandanaran No.405, Boyolali, Jawa Tengah, 57315 Indonesia \\ ${ }^{\mathrm{b}}$ Fakultas Pertanian, Universitas Boyolali, Jl. Pandanaran No.405, Boyolali, Jawa Tengah, 57315 Indonesia \\ rikadesi4@gmail.com; ${ }^{2}$ sigit.ms2013@gmail.com* \\ * Koresponsendi penulis
}

\section{ARTICLE INFO}

Article history

Menerima 4 April 2021

Revisi 6 Juli 2021

Diterima 21 Juli 2021

Kata Kunci

Digital MSMEs

Products

Covid-19

\section{ABSTRACT (10PT)}

This article aims to develop Micro, Small and Medium Enterprises (MSMEs) during the Covid-19 pandemic. As a result of the Covid-19 pandemic, Micro, Small and Medium Enterprises (MSMEs) experienced a decline in sales, late distribution and difficult in raw materials. Business actors must create new products to increase sales in order to revive their business, not only that, the behavior of Micro, Small and Medium Enterprises (MSMEs) must shift their business from offline to digital business. Social media and maker places (intermediaries) can be a concept to facilitate the behavior of Medium Small and Medium Enterprises (MSMESs) to gain wider marketing access.

\section{Pendahuluan}

Pandemic Covid-19 saat ini sangat berpengaruh di semua sektor kehidupan masyarakat [1] [2]. Upaya pencegahan penyebaranpun dilakukan dan dikampanyekan dengan cara menjaga jarak dan rajin mencuci tangan dengan sabun [3]. Pemerintah dalam mengatasi pandemic mulai memberlakukan Pembatasan Sosial Berskala Besar (PSBB). Peraturan ini memiliki efek nyata pada masyarakat[4]. Akibat COVID-19 ini tidak hanya menghantam sektor kesehatan dan pelayanan publik, melainkan juga melumpuhkan berbagai sektor kehidupan manusia lainnya, termasuk sektor usaha mikro di seluruh dunia [5]. Sektor Usaha Mikro Kecil Menengah (UMKM) yang merupakan bagian terpenting dari sektor ekonomi sangat meresahkan dampaknya [6]. Peranan dan kegiatan usaha sektor UMKM sangat menurun akibat virus Covid-19 seperti penurunan penjualan, permodalan, distribusi terlambat, dan kesulitan bahan baku. Menurut UU No 20 Tahun 2008 UMKM adalah usaha perdagangan yang dikelola oleh perorangan yang merujuk pada usaha ekonomi produktif dengan kriteria yang sudah ditetapkan undang-undang.

Di Desa Bendo terdapat sebuah UMKM yang memproduksi lempeng singkong. Lempeng adalah sebuah makanan/ snack yang terbuat dari singkong yang dibumbui dengan cara dikukus kemudian dihaluskan dan dicetak tipis kemudian dikeringkan dengan sinar matahari. Semenjak adanya pandemic Covid 19 UMKM lempeng sempat berhenti berproduksi karena kurangnya permintaan pelanggan. Kemudian mahasiswa kkn mengajak pelaku UMKM untuk berinovasi dengan cara menciptakan produk lempeng dengan berbagai varian rasa seperti pedas manis, 
bbq, balado dan original. Tidak hanya itu UMKM lempeng juga membuat kemasan yang lebih menarik dengan disertai logo sebagai tanda pengenal dan salah satu cara untuk memasarkan produk. Sehingga produk dapat bersaing di e-commerce saat ini.

Dengan adanya pandemic Covid-19 pelaku usaha harus mengalihkan bisnisnya dari offline menuju bisnis digital Media sosial. Hal ini sangat cocok untuk mencapai pangsa pasar sasarannya sehingga dapat meningkatkan penjualan [7]. Di zaman sekarang dengan perkembangan teknologi dan komunikasi yang semakin canggih, pemilihan penggunaan pemasaran melalui media sosial menjadi pilihan utama yang dilakukan oleh pelaku usaha, sekarang ini media sosial telah menjadi pilar utama dalam penyampaian informasi [8]. Media sosial kini menjadi trend dalam komunikasi pemasaran. Contoh-contoh media social yang berkembang saat ini adalah: twitter, facebook, myspace, youtube, instagram, path, whatsapp, line, dll[9]. Keunggulan media sosial online adalah memiliki system koneksi dan informasi yang luas tanpa dibatasi oleh teritori [10]. Namun masih banyak pengusaha UMKM di dusun Bendo yang kurang mengerti dengan pemanfaatan media online untuk pemasaran bisnisnya, mereka masih melakukan pemasaran secara tradisional yaitu dengan memasarkan produk langsung kepada konsumen dan hanya mencakup wilayah yang kecil.

Edukasi ini akan lebih mengelaborasi pengembangan UMKM berbasis digital di masa pandemi Covid-19. Pengembangan ini juga meliputi pemanfaatan, market place, media sosial, dan berbagai aplikasi pendukung lainnya.

\section{Metode}

Kegiatan penyuluhan UMKM yang dilaksanakan sebagai bentuk pengabdian kepada masyarakat [11] yang diikuti oleh 2 kelompok pelaku UMKM Lempeng di Dusun Bendo, Desa Seboto, Kecamatan Gladagsari, Kabupaten Boyolali

Tahap pertama, mencari dan mengumpulkan data warga Dukuh Bendo yang memiliki UMKM melalui wawancara ketua RT 01 Dukuh Bendo, Desa Seboto, Kecamatan Gladagsari, Kabupaten Boyolali. Syarat peserta penyuluhan yaitu: warga asli dukuh bendo dan pemilik UMKM

Tahap kedua, persiapan pelaksanaan penyuluhan, persiapan dimulai dengan menata tempat yang akan digunakan penyuluhan, yaitu di rumah ibu tarminah salah satu pemilik UMKM lempeng, kemudian menyiapkan alat-alat untuk melakukan penyuluhan

Tahap ketiga, pelaksanaan penyuluhan UMKM. Penyuluhan UMKM dilaksanakan pada tanggal 26 Februari 2021 yang bertempat di RT 01, Dukuh Bendo, Desa Seboto, Kecamatan Gladagsari, Kabupaten Boyolali. Pelaksanaan diawali dengan: Pembukaan yang dilakukan oleh Rika Desi Ernawati, kemudian menyapaikan materi penyuluhan tentang pengembangan UMKM dengan transformasi digital dalam rangka pertahanan ekonomi ditengah pandemic, sesi tanya jawab, dan terakhir penutup

\section{Hasil dan Pembahasan}

Pelaksanaan kegiatan pengabdian KKN Universitas Boyolali yang dilaksanakan pada tanggal 20 Februari 2021 sampai 31Maret 2021 [12]. Tahapan yang dilakukan dalam kegiatan KKN didusun bendo ini adalah mengajak pelaku UMKM untuk mengembangkan UMKM dengan transformasi digital dalam rangka pertahanan ekonomi ditengah pandemic Covid-19. Kegiatan ini akan melibatkan warga desa yang telah mempunyai usaha sebelumnya dan yang mengalami masalah dalam pemasaran produk ditengah pandemic ini. Mahasiswa KKN mengajak pelaku UMKM untuk berinovasi dalam mengembangkan produk dengan cara memberi varian rasa pada produk tersebut agar pelanggan tidak mudah bosan. Dan memberikan cara pengemasan yang lebih menarik dan memberikan logo sebagai tanda pengenal sehingga produk dapat bersaing dengan produk lain dan dapat dipasarkan dimedia soSial ataupun ecommerce. 
Media sosial saat ini merupakan situs yang menjadi wadah untuk memudahkan semua orang untuk berkomunikasi, berpartisipasi, saling bertukar informasi dan membentuk sebuah jaringan online dengan teman dan kerabat, baik yang dikenal didunia nyata maupun dunia maya sedangkan Usaha Elektronik Commerce (E-Commerce) adalah pelaksanaan perniagaan berupa transaksi penjualan, pembelian, pemesanan, pembayaran, maupun media promosi suatu produk barang/jasa yang dilakukan dengan memanfaatkan komputer dan sarana komunikasi elektronik digital [13].

Berdasarkan observasi yang telah dilakukan ternyata banyak pengusaha UMKM mengalami banyak hambatan [14]diantaranya pelaku UMKM "Lempeng" memiliki keterbatasan didalam penguasaan informasi teknologi. Sementara tuntutan kebutuhan atas penggunaan dan penguasaan teknologi informasi tersebut sudah terasa semakin mendesak mengingat tingkat persaingan di pasar local, regional maupun global, dimana setiap pelaku usaha sudah mulai dituntut untuk mampu menyajikan informasi secara cepat dan akurat kepada pelanggannya [15]. Tidak hanya itu pelaku UMKM kripik "Lempeng" juga kurang menguasai cara pengemasan produk yang menarik untuk dapat dijual secara online dan dapat menarik pelanggan. Dengan pendampingan kurang lebih selama satu bulan mahasiswa kkn mendampingi pelaku UMKM dengan menciptakan produk baru sehingga sekarang produk tersebut sudah dapat dipasarkan dimedia sosial seperti instagram dan facebook.

Berdasarkan permasalahan diatas mahasiswa KKN Universitas Boyolali mengajak berinovasi dan memotivasi pengusaha UMKM di Dusun Bendo untuk mulai mengembangkan potensi yang telah dimiliki di Dusun mereka kemudian diharapkan mampu meningkatkan taraf hidup di kemudian harinya. Karna saat ini pelaku UMKM lempeng hanya menjual produk dengan cara dijual mentah dan dijual perkilo yang kemudian hanya dijual dalam lingkup desa secara offline. Mahasiswa KKN mengajak pelaku UMKM lempeng untuk meningkatkan usahanya dengan cara memberi logo/stiker sebagai tanda pengenal produk, memberikan contoh pengemasan yang menarik yang dapat dijual secara online dan memberikan berbagai varian rasa pada produk kripik lempeng sehingga konsumen bisa merasakan berbagai varian rasa yang tidak hanya rasa original.

UMKM dengan wujud kegiatan memberikan materi dan motivasi agar dapat mengubah cara berfikir, agar memiliki keberanian dalam memasarkan suatu produk secara online, berinovasi dalam pengembangan pengemasan produk menjadi lebih modern. Sehingga dapat membantu perekonomian keluarga dan dapat menciptakan lapangan kerja yang baru.

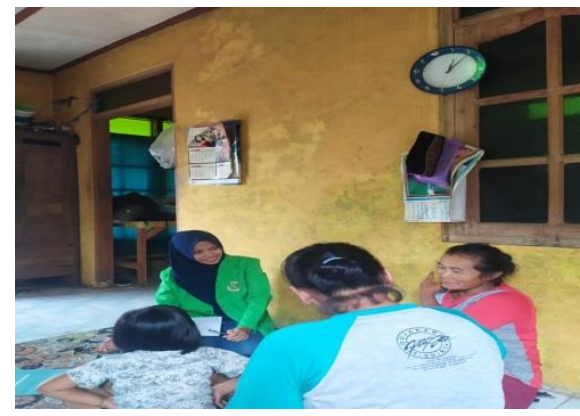

Fig. 1. Menyampaikan materi tentang pengembangan UMKM dengan transformasi digital dalam rangka pertahanan ekonomi ditengah pandemic covid 19 


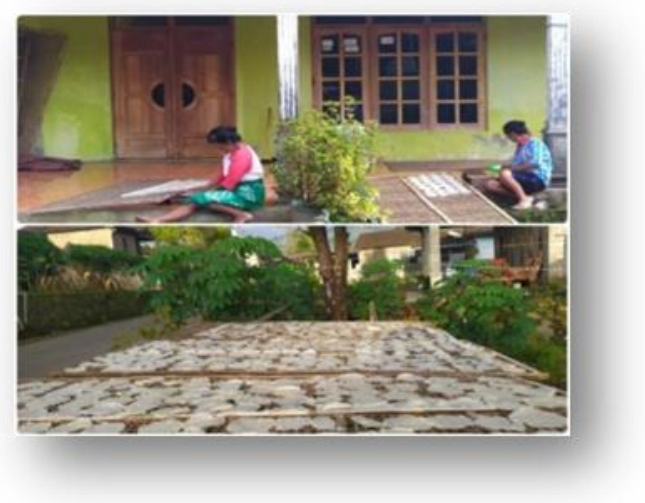

Fig. 2. Proses pembuatan Lempeng dan pengeringan lempeng yang dilakukan oleh pelaku usaha UMKM

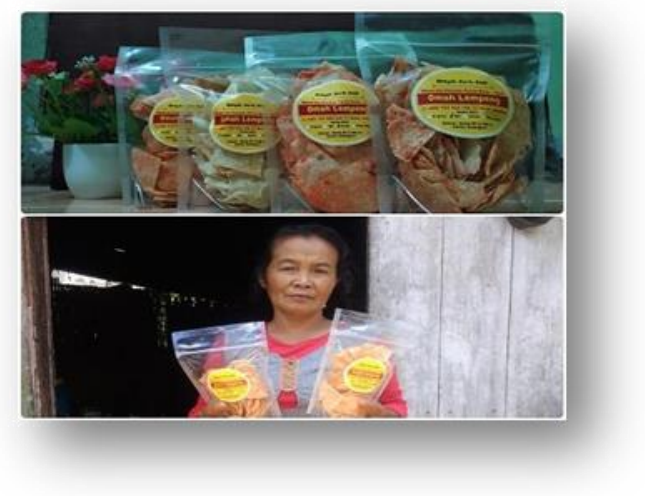

Fig. 3. Hasil pengemasan Lempeng yang sudah diberi logo dan varian rasa yang dapat dijual online

\section{Kesimpulan}

Program KKN Universitas Boyolali yang dilaksanakan di Dusun Bendo, Seboto, Gladagsari, Boyolali tentang pengembangan UMKM dengan transformasi digital dalam rangka pertahanan ekonomi ditengah pandemic coviid-19 dapat berjalan dengan lancar dan sukses. Tujuan dan targes sudah tercapai yaitu mengajak pelaku UMKM untuk berinovasi akan produk yang akan dijual menjadi lebih menarik, dan menjual produk secara online guna memenuhi kebutuhan hidup selama masa pandemic covid-19.

Sedangkan saran yang diberikan adalah untuk pelaku UMKM sebaiknya dapat memanfaatkan media sosial seperti instagram dan facebook yang sudah dibuatkan oleh mahasiswa KKN seoptimal mungkin sebagai sarana promosi secara maksimal. Dan pengusaha UMKM dapat menambah usaha untuk mengembangkan usahanya.

\section{Ucapan Terima Kasih}

Puji sykur alhamdulilah penulis panjatkan kepada Allah SWT yang telah memberikan rahmat dan hidayahnya kepada penulis. Sehingga penulis selalu diberikan kelancaran dalam membuat jurnal ini. Tidak lupa saya mengucapkan terima kasih kepada bapak sigit muryanto selaku pembimbing dalam pelaksanaan kkn didusun bendo, seluruh masyarakat dusun bendo khususnya pelaku usaha UMKM yang ikut serta dalam kegiatan KKN ini dan seluruh pihak yang telah membantu dalam kegiatan KKN ini. Sehingga setiap program kegiatan dapat berjalan dengan baik dan lancar. 


\section{Daftar Pustaka}

[1] W. E. Al., "Sosialisasi Strategi UMKM Beradaptasi di Kala Pandemi Covid 19 bagi Masyarakat Kelurahan Kalicari Kecamatan Pedurungan Kota Semarang Ratna Wijayanti , SE, MM Dibiayai oleh Universitas Semarang sesuai dengan Perjanjian Pelaksanaan Pengabdian kepada Masyar," no. 145, 2021.

[2] R. Monoarfa, “19860309 2008012 003.”

[3] R. Rosita, "Pengaruh Pandemi Covid-19 Terhadap Umkm Di Indonesia," J. Lentera Bisnis, vol. 9, no. 2, p. 109, 2020, doi: 10.34127/jrlab.v9i2.380.

[4] D. Chaerani, M. N. Talytha, T. Perdana, E. Rusyaman, and N. Gusriani, "Pemetaan Usaha Mikro Kecil Menengah (Umkm) Pada Masa Pandemi Covid-19 Menggunakan Analisis Media Sosial Dalam Upaya Peningkatan Pendapatan," Dharmakarya, vol. 9, no. 4, p. 275, 2020, doi: 10.24198/dharmakarya.v9i4.30941.

[5] N. Nur and L. L. Wijayanti, "Pendampingan Usaha Mikro Yang Terdampak Covid-19 Melalui Pelatihan Penggunaan Media Sosial Dalam Pemasaran Produk," J. Umj, pp. 2-6, 2020.

[6] B. Arianto, "Pengembangan UMKM Digital di Masa Pandemi Covid-19," ATRABIS J. Adm. Bisnis, vol. 6, no. 2, pp. 233-247, 2020.

[7] F. D. H. P. Mansir, "Pemberdayaan Masyarakat Melalui Digital Marketing dan Media Sosial Sebagai Media Promosi Era Pandemi Covid -19 di UMKM Panggungharjo Sewon Bantul," Abdimas Singkeru, vol. 1, no. 1, pp. 39-50., 2021.

[8] Z. Abidin Achmad, T. Zendo Azhari, W. Naufal Esfandiar, N. Nuryaningrum, A. Farah Dhilah Syifana, and I. Cahyaningrum, "Pemanfaatan Media Sosial dalam Pemasaran Produk UMKM di Kelurahan Sidokumpul, Kabupaten Gresik," J. Ilmu Komun., vol. 10, no. 1, pp. 17-31, 2020, doi: 10.15642/jik.2020.10.1.17-31.

[9] M. H. Purwidiantoro, D. F. Kristanto, and W. Hadi, "Pengaruh Penggunaan Media Sosial Terhadap Usaha Kecil Menengah (UKM)," AMIK Cipta Darma Surakarta, vol. 1, no. 1, pp. 30-39, 2016, [Online]. Available:

http://journal.amikomsolo.ac.id/index.php/ekacida/article/view/19/11.

[10] O. Fernández, S. Kang, J. T. M. Laily Noor Ikhsanto, and K. T. K. Aceh, “No 主観的健康感を中心とした在宅高齢者における 健康関連指標に関寸る共分散構造分析Title,” vol. 2017, no. 1, pp. 1-9, 2020.

[11] F. I. Farizki, R. Salamah, T. S. R. Mutiah, W. K. Wardhani, and P. Siddi, "Penyuluhan Umkm Di Era New Normal Dengan Memprioritaskan Ekonomi Digital Marketing," SELAPARANG J. Pengabdi. Masy. Berkemajuan, vol. 4, no. 1, p. 620, 2020, doi: 10.31764/jpmb.v4i1.3374.

[12] P3Kkn-Unib, "Panduan KKN Mandiri 91 Tahun 2020,” pp. 1-28, 2020.

[13] C. Winarti, "Pemanfaatan Sosial Media oleh UMKM Dalam Memasarkan," Univ. Tanjungpura, pp. 195-206, 2021. 
[14] A. U. Ulya, D. Agustin, and P. Ketiga, "PEGEMBANGAN STRATEGI PEMASARAN MELALUI E-MARKETING PADA UMKM DESA SUMBER,” vol. 2, no. 2, pp. 2-5, 2019.

[15] S. Hadi, A. F. Wijaya, and B. S. Utami, "Pemberdayaan Umkm Berbasis Teknologi Informasi Dan Komunikasi Kabupaten Kendal Menuju Pasar Global,” J. Inform., vol. 12, no. 1, pp. 51-66, 2016, doi: 10.21460/inf.2016.121.422. 